\title{
PENINGKATAN KETERAMPILAN ECOPRENEUR PADA MASA PENDEMIC COVID-19 MELALUI PELATIHAN BUDIDAYA TANAMAN SAYUR HIAS ORGANIK
}

${ }^{1}$ Suharjuddin, ${ }^{2}$ Apriyanti Widiansyah, ${ }^{3}$ Yohamintin

123 Universitas Bhayangkara Jakarta Raya

Email: suharjuddin@dsn.ubharajaya.ac.id

\section{RINGKASAN}

Keterampilan kewirausahaan berbasis lingkungan (eco-preneur) perlu diberikan kepada semua lapisan masyarakat. Melalui budidaya vertikultur yang melibatkan Ibu-ibu PKK di Perumahan Mustika Karang Satria Tambun Utara, selain berdampak langsung bagi penghijauan di lingkungan perumahan, juga dapat menjadi sarana kewirausahaan berbasis lingkungan dan terutama meningkatkan ketahanan pangan keluarga pada masa pendemic Covid-19. Alasan dipilihnya lembaga PKK di lingkungan ini adalah berdasarkan survei, lokasi perumahan berada di kawasan padat penghuni dan mempunyai lahan yang sempit. Keterbatasan lahan berakibat minimnya penghijauan di lingkungan perumahan. Padahal sumber daya manusia (Ibu-ibu PKK) di lingkungan perumahan memiliki potensi untuk pengembangan diri cukup yang besar sebagai agen wirausaha, khususnya eco-preneur. Akan tetapi mereka kurang memiliki pengetahuan serta tidak adanya pelatihan yang mendorong mereka untuk pengembangan diri. Oleh karena itu, lingkungan ini memerlukan bantuan pemecahan persoalan dalam menyediakan media pelatihan eco-preneur; Metode kegiatan Pengabdian Kepada Masyarakat (PKM) ini menggunakan metode ceramah, pelatihan dan teknik penanaman vertikultur organik serta evaluasi efektifitas dan efisiensi prototype tanaman sayur hias organik, yang telah dipraktekan oleh narasumber serta sesi tanya jawab. Pelatihan ini melibatkan dosen Fakultas Ilmu Pendidikan yang bekerjasama dengan lembaga PKK Ibu di Perumahan Mustika Karang Satria Tambun Utara. Kegiatan pengabdian masyarakat dilaksanakan pada pada hari/tanggal Senin-Selasa, 07-08 Februari 2020, pukul 09.00-13.00 WIB bertempat di Lingkungan Perumahan Mustika Karang Satria Tambun Utara, Kabupaten Bekasi.

Kata kunci: Eco-prenuer, Vertikultur Organik, Ketahanan Pangan Keluarga

\section{A. Latar Belakang \\ 1. (Analisis Situasi)}

Aktivitas manusia dapat menimbulkan permasalahan lingkungan, jika dalam melakukan aktivitas tersebut tidak memperhatikan pengelolaan sumberdaya dengan 
tepat dan menggunakan bahan-bahan yang ramah lingkungan. Salah satu di antaranya adalah aktivitas di bidang pertanian. Akibat penggunaan pupuk ataupun pestisida berbahan kimia sintetis yang terus-menerus akan menghasilkan limbah yang potensial menjadi pencemar jika melebihi nilai ambang batas. Baik secara langsung ataupun tidak langsung kita akan terkena efek buruknya, apalagi jika hasil pertanian juga terkena polutan. Begitu pula di perkotaan persoalan lingkungan semakin kompleks karena semakin beragam pula aktivitas warganya. Sebagai konsumen hasil pertanian, warga kota seyogyanya waspada terhadap bahayabahaya yang bersumber dari produk-produk yang mungkin tercemar bahan-bahan berbahaya.

Dewasa ini, permasalahan lingkungan telah menjadi isu global (mendunia), setelah hampir semua elemen masyarakat menyadari akan bahaya yang ditimbulkan dari kerusakan lingkungan. Kini masyarakat menjadi semakin arif dalam memilih bahan pangan yang aman bagi kesehatan dan ramah lingkungan. Gaya hidup sehat dengan slogan "Back to Nature"telah menjadi kecenderungan baru di segala aspek kehidupan termasuk dalam bidang pertanian. Dengan meninggalkan penggunaan pupuk dan pestisida berbahan kimia sintetis dan hormon pertumbuhan dalam industri pertanian merupakan satu upaya untuk menghasilkan produk yang ramah lingkungan dan aman bagi kesehatan. Bahan makanan yang sehāt dan bergizi dapat diperoleh dari pertanian organik. Pertanian organik adalah cara menanam tanaman secara alami dengan penekanan terhadap perlindungan lingkungan dan pelestarian tanah serta sumber air yang berkelanjutan. Pertanian organik menggunakan pupuk dan pestisida biologi tanpa bahan kimia sehingga melindungi tanah, udara, tanaman dan hewan. Dengan demikian jika kita mengonsumsi makanan yang berasal dari tanaman organik, kita dapat hidup lebih sehat karena terhindar dari racun yang berbahaya.

Pada umumnya di perkotaan untuk menanam tanaman yang kita inginkan kadang- kadang kita terkendala oleh luas lahan. Untuk mengatasi lahan yang sempit 
kita bisa menanam tanaman secara vertikultur. Sistem vertikultur adalah sistem budidaya pertanian yang dilakukan secara vertikal atau bertingkat. Sistem ini cocok diterapkan di lahan-lahan sempit atau di pemukiman yang padat penduduknya. Jenis tanaman yang dapat ditanam secara vertikultur ini sangat banyak, biasanya dari komoditas sayuran, tanaman hias ataupun komoditas tanaman obat yang dikenal dengan sebutan tanaman hortikultura.

Jenis tanaman yang dapat ditanam secara vertikultur ini sangat banyak, biasanya dari komoditas sayuran, tanaman hias ataupun komoditas tanaman obat yang dikenal dengan sebutan tanaman hortikultura. Tanaman yang termasuk komoditas sayuran antara lain: sawi, kucai, pakcoi, kangkung, bayam, kemangi, caisim, seledri, selada bokor dan bawang daun. Budidaya tanaman sayuran secara vertikultur ini dapat dilakukan di pekarangan rumah untuk memenuhi kebutuhan pangan dan gizi keluarga dan juga mengurangi pengeluaran keluarga untuk belanja sayuran. Model budidaya secara vertikultur dapat berupa: Model gantung, Model tempel, Model Tegak dan Model Rak.

Terkait dengan permasalahan lingkungan, Melalui budidaya vertikultur yang melibatkan Ibu-ibu PKK di Perumahan Mustika Karang Satria Tambun Utara, selain berdampak langsung bagi penghijauan di lingkungan perumahan, juga dapat menjadi sarana kewirausahaan berbasis lingkungan dan terutama meningkatkan ketahanan pangan keluarga pada masa pendemic Covid-19

\section{Tujuan Kegiatan}

a. Memberikan pengetahuan melalui kegiatan program pengabdian dan pemberdayaan masyarakat.

b. Meningkatkan keterampilan eco-preneur bagi masyarakat melalui pelatihan budidaya tanaman sayur organik.

c. Memberikan solusi untuk meningkatkan ketahanan pangan keluarga di masa pendemic covid-19

\section{Manfaat Kegiatan}

a. Pemecahan persoalan dalam menyediakan media pelatihan eco-preneur. 
b. Penghijauan di lingkungan perumahan, juga dapat menjadi sarana kewirausahaan berbasis lingkungan.

c. Meningkatnya ketahanan pangan keluarga secara mandiri pada masa pendemic covid-19

\section{Luaran}

Indikasi keluaran (output) dari dari program pengabdian masyarakat ini adalah Jurnal Pengabdian Kepada Masyarakat dan selain itu output dari kegiatan ini adalah terciptanya prototype tanaman sayur hias organik dengan model hidroponik yang berfungsi sebagai tanaman hias dan sekaligus sumber sayuran bagi masyarakat. Serta dihasilkannya modul panduan budidaya hidroponik yang mudah dipahami dan dapat dijadikan rujukan implementasi bagi para peserta.

\section{B. Metode Pelaksanaan}

Pengabdian kepada masyarakat ini merupakan keberlanjutan dari perencaan dan implementasi Eco-Preneur pada ibu-ibu PKK di Perumahan Mustika Karang Satria melalui pelatihan budidaya tanaman sayur hias organic. Berikut ini adalah rincian metode pelakanaan yang dilakukan

\section{Waktu dan Tempat}

Kegiatan pengabdian masyarakat ini dilaksanakan pada pada hari/tanggal SeninSelasa, 07-08 Februari 2020, pukul 09.00-13.00 WIB bertempat di Lingkungan Perumahan Mustika Karang Satria Tambun Utara, Kabupaten Bekasi. 
Gambar1. Peta Lokasi Wilayah

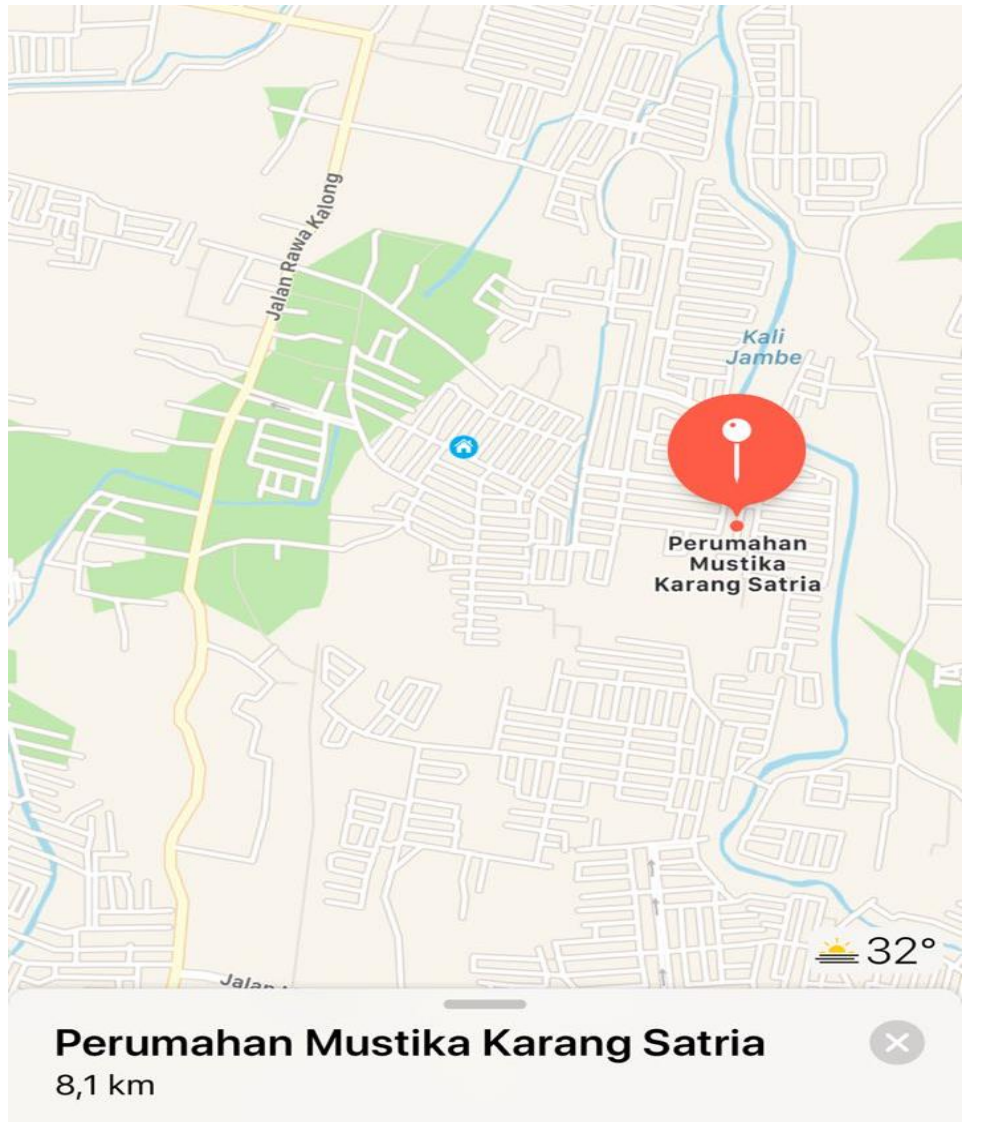

\section{Khalayak}

Sasaran/Mitra Kegiatan

Unsur penting dalam

rangkaian abdimas ini adalah mengumpulkan data-data serta fakta yang relevan mengenai kegiatan yang akan dilakukan yang sebelumnya didahului dengan penentuan lokasi dengan metode Purposive Decision Location yaitu perumahan yang memiliki lahan terbatas namun masih memiliki space/ halaman/pekarangan untuk implementasi tanaman hidroponik serta memiliki keaktifan kelompok PKK. Sehingga dilakukan survey di beberapa tempat dan ditentukan bahwa lokasi abdimas yaitu di Perumahan Mustika Karang Satria Tambun Utara Bekasi sebagai lokasi yang memenuhi kriteria lokasi untuk pengabdian kepada masyarakat.

PKK adalah gerakan yang tumbuh dari bawah dengan wanita sebagai motor / penggeraknya untuk membangun keluarga sejahtera sebagai unit atau kelompok terkecil dalam masyarakat. Gerakan PKK adalah mitra kerja pemerintah dan organisasi kemasyarakatan, yang mekanismenya dikelola dan dilaksanakan secara berjenjang, dari tingkat terbawah (Dawis, Banjar), Desa, hingga pusat.

PKK Mustika Karang Satria yang menjadi mitra dalam kegiatan pengabdian kepada masyarakat ini memiliki visi "Terwujudnya Keluarga yang beriman dan 
bertaqwa kepada Tuhan Yang Maha Esa, berahlak mulia dan berbudi luhur, sehat sejahtera, maju dan mandiri, berkesetaraan dan berkeadilan gender serta kesadaran hukum dan kesadaran lingkungan"

\section{Realisasi Pemecahan Masalah}

Pemecahan masalah ditarik dari tema pengabdian kepada masyarakat yang disusun bersama oleh kelompok dosen yang berasal dari internal Program Studi FIP Ubhara jaya dengan melakukan diskusi bersama dengan prinsip musyawarah mufakat. Dengan menggabungkan keterampilan dan kompetensi yang dimiliki oleh tim pengabdian masyarakat maka diangkatlah tema "Edukasi masyarakat berbasis lingkungan dan wirausaha".

Setelah menentukan tema sentral dan lokasi penelitian, dalam tahap persiapan, juga dilakukan studi pustaka. Studi pustaka dilaksanakan sejak tahap penyusunan proposal dan dilengkapi pada proses penyusunan laporan pelaksanakan pengabdian kepada masyarakat.

Berdasarkan studi pustaka yang telah dilakukan, maka dibuatlah materi pelatihan perencanaan dan implmentasi eco-preneur yang dibuatkan ke dalam modul mengenai pengertian, pemahaman dan penggunaannya dalam kegiatan penghijauan berbasis lingkungan. Materi pelatihan yang disusun berupa modul tata cara budidaya tanaman sayuran hias dengan metode hidropinik (materi terlampir) sebagai salah satu alternative dalam rangka peningkatan ketahanan pangan keluarga pada masa pendemic Covid-19.

Pelatihan ini dilaksanakan dengan metode ceramah, diskusi, simulasi dan praktek. Pelatihan (training) adalah suatu proses pendidikan jangka pendek yang mempergunakan prosedur sistematis dan terorganisir untuk mempelajari pengetahuan dan keterampilan teknis dalam tujuan terbatas (Andrew E. Sikula)

Pemberdayaan Ibu-ibu PKK di wilayah kabupaten Bekasi, khususnya di Tambun Utara ini dilaksanakan melalui pelatihan Eco-preneur yang 
diselenggarakan di Perumahan Mustika Karang Satria, Kec. Karang Satria, Kab. Bekasi, provinsi Jawa Barat. Peserta pelatihan adalah Ibu-ibu Rumah Tangga serta Ibu-ibu PKK dengan karakteristik antara lain: ibu-ibu rumah tangga yang memiliki potensi pengembangan diri, dan hidup dilingkungan minim pekarangan yang memadai atau bahkan sama sekali tidak memiliki pekarangan untuk lahan penghijauan dengan jumlah peserta adalah 20 orang. Dengan waktu pelaksanaan pelatihan selama 2 hari dan proses pendampingan selama 2 minggu.

\section{Metode Evaluasi}

Model-model evaluasi ada yang dikatagorikan berdasarkan ahli yang menemukan dan yang mengembangkannya dan ada juga yang diberi sebutan berdasarkan sifat kerjanya. Dalam hal ini Stephen Isaac (1986, dalam Fernandes 1984) mengatakan bahwa model-model tersebut diberi nama sesuai dengan fokus atau penekanannya. Lebih jauh Isaac membedakan adanya empat hal yang digunakan untuk membedakan ragam model evaluasi, yaitu :

1. Berorientasi pada tujuan program

2. Berorientasi pada keputusan-decision oriented

3. Berorientasi pada kegiatan dan orang-orang yang menanganinya-transactional oriented.

4. Berorientasi pada pengaruh dan dampak program-research oriented.

Model evaluasi yang digunakan dalam pengabdian kepada masyarakat ini yaitu tufflebeam's Model (CIPP Model). Model ini mula-mula dikembangkan oleh Stufflebeam dan Guba tahun 1968. CIPP merupakan kependekan dari Context, Input, Prosess, and Product. Stufflebeam membuat batasan (merumuskan) terlebih dahulu tentang pengertian evaluasi sebagai "educational evalution is the process of obtaining and providing useful information for making educational decisions" (Evaluasi pendidikan merupakan proses penyediaan/pengadaan informasi yang berguna untuk membuat keputusan dalam bidang pendidikan). 


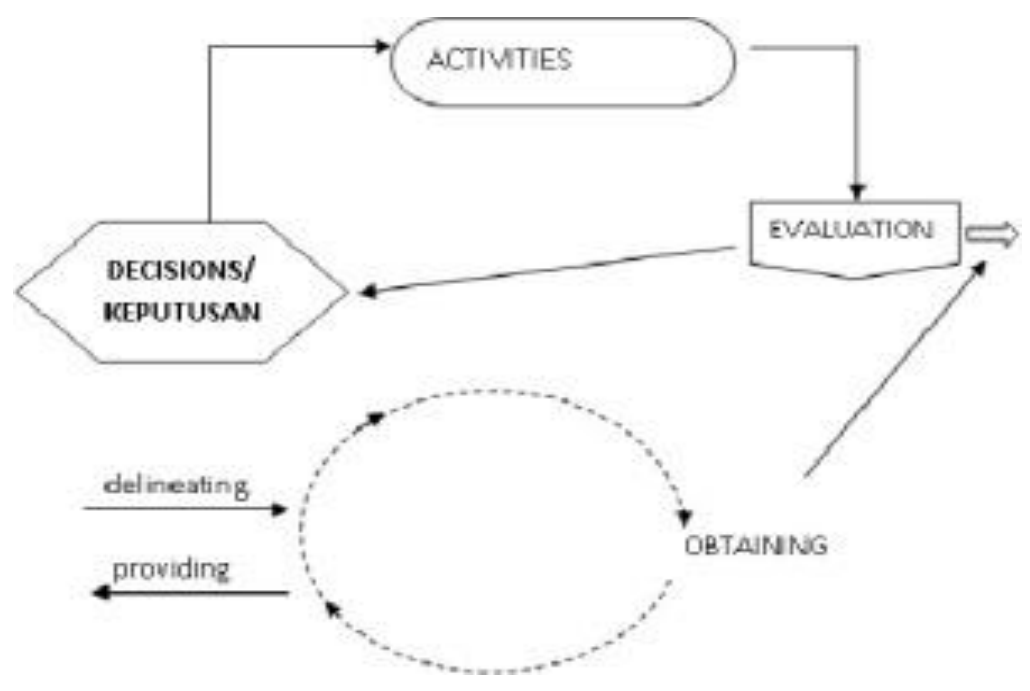

Gambar 2. Hubungan antara Evaluasi dengan Pengambilan Keputusan

Keunikan model ini adalah pada setiap tipe evaluasi terkait pada perangkat pengambil keputusan (decission) yang menyangkut perencanaan dan operasional sebuah program. Keunggulan model CIPP memberikan suatu format evaluasi yang komprehensif/menyeluruh pada setiap tahapan evaluasi yaitu tahap konteks, masukan, proses, dan produk.

Model CIPP ini bertitik tolak pada pandangan bahwa keberhasilan program dipengaruhi oleh berbagai faktor, seperti: karakteristik peserta dan lingkungan, tujuan program dan peralatan yang digunakan, prosedur dan mekanisme pelaksanaan program itu sendiri.

Model evaluasi ini merupakan model yang paling banyak dikenal dan diterapkan oleh para evaluator. Model CIPP yang merupakan sebuah singkatan dari huruf awal empat buah kata, yaitu

Context evaluation: evaluasi terhadap konteks

Input evaluation: evaluasi terhadap masukan

Process evaluation: evaluasi terhadap proses 
Product evaluation: evaluasi terhadap hasil

Keempat kata yang disebutkan dalam singkatan CIPP tersebut merupakan sasaran evaluasi, yang tidak lain adalah komponen dari proses sebuah program kegiatan. Dengan kata lain, model CIPP adalah model evaluasi yang memandang program yang dievaluasi sebagai sebuah sistem.

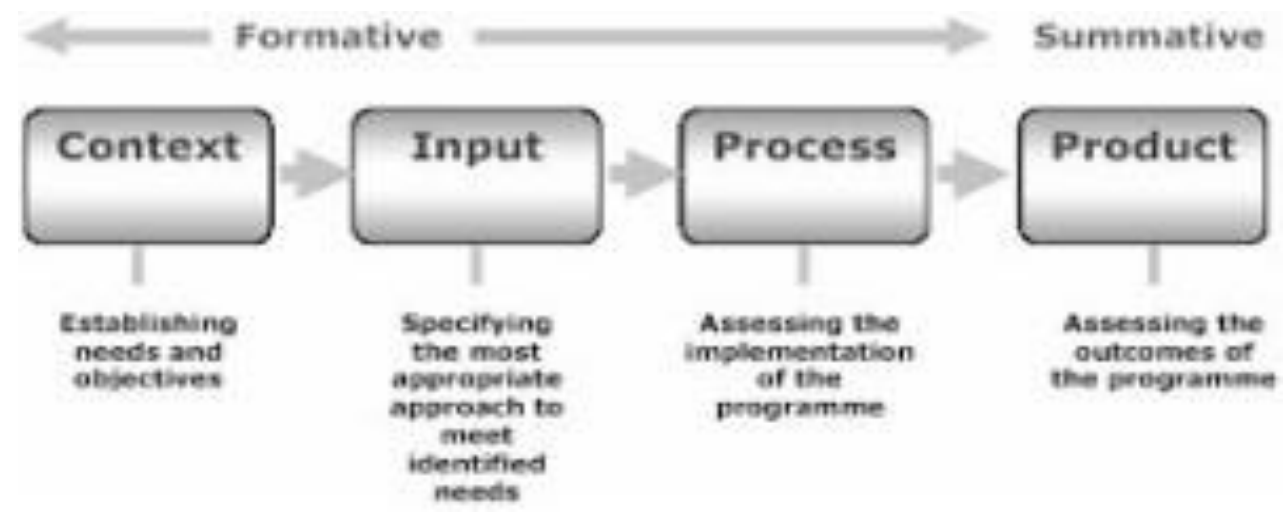

Context Pormative Input Process

Empat aspek Model Evaluasi CIPP (Context, Input, Process and Output) membantu pengambil keputusan untuk menjawab empat pertanyaan dasar mengenai:

Apa yang harus dilakukan (What should we do?) mengumpulkan dan menganalisa needs assessment data untuk menentukan tujuan, prioritas dan sasaran.

Bagaimana kita melaksanakannya (How should we do it?) sumber daya dan langkah-langkah yang diperlukan untuk mencapai sasaran dan tujuan dan mungkin meliputi identifikasi program eksternal dan material dalam mengumpulkan informasi.

Apakah dikerjakan sesuai rencana (Are we doing it as planned?) Ini menyediakan pengambil-keputusan informasi tentang seberapa baik program diterapkan. Dengan secara terus-menerus monitoring program, pengambilkeputusan mempelajari seberapa baik pelaksanaan telah sesuai petunjuk dan 
rencana, konflik yang timbul, dukungan staff dan moral, kekuatan dan kelemahan material, dan permasalahan penganggaran.

Apakah berhasil (Did it work?); Dengan mengukur outcome dan membandingkannya pada hasil yang diharapkan, pengambil-keputusan menjadi lebih mampu memutuskan jika program harus dilanjutkan, dimodifikasi, atau dihentikan sama sekali.

Berikut disajikan alur pelaksanaan pengabdian kepada masyarakat:

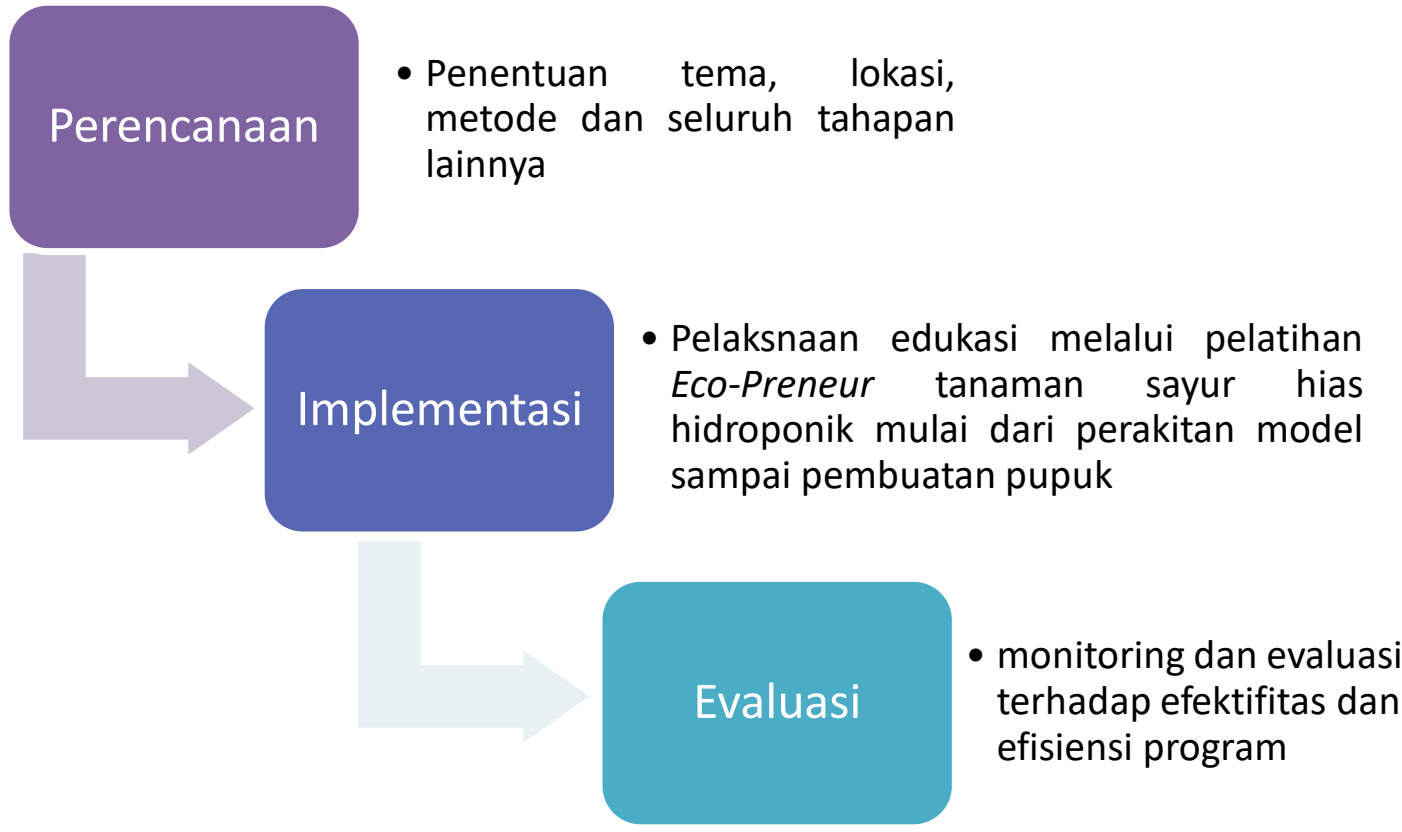

Dalam pelaksanaan evaluasi sejumlah pertanyaan inti disusun untuk dijadikan pandual dalam evaluasi dengan model CIPP diantaranya:

1. Kebutuhan apa saja yang belum terpenuhi oleh?

2. Tujuan pengembngan apakah yang belum tercapai oleh program, misalnya?

3. Tujuan pengembangan apakah yang dapat membantu mnegembangkan masyarakat?

4. Tujuan-tujuan manakah yang paling mudah dicapai,?

5. Kemampuan Sumber daya manusia dalam mengelola tanaman hidroponik

6. Kecukupan sarana dan peralatan pendukung program? 
7. Kesesuaian prosedur dan aturan yang telah ditetapkan?

8. Apakah pelaksanaan program sesuai dengan jadwal?

9. Apakah masyarakat yang terlibat didalam pelaksanaan program akan sanggup menangani kegiatan selama program berlangsung dan kemungkinan jika dilanjutkan?

10. Apakah sarana dan prasarana yang disediakan dimanfaatkan secara maksimal?

11. Hambatan-hambatan apa saja yang dijumpai selama pelaksanaan program dan kemungkinan jika program dilanjutkan?

12. Apakah tujuan-tujuan yang ditetapkan sudah tercapai?

13. Pernyataan-pernyataan apakah yang mungkin dirumuskan berkaitan antara rincian proses dengan pencapaian tujuan?

14. Dalam hal apakah berbagai kebutuhan masyarakat sudah dapat dipenuhi selama proses implementasi

15. Apakah dampak yang diperoleh masyarakat dalam waktu yang relatif singkat dengan adanya program tanaman sayur hias dengan metode tanam hidroponik ini?

\section{Hasil dan Pembahasan}

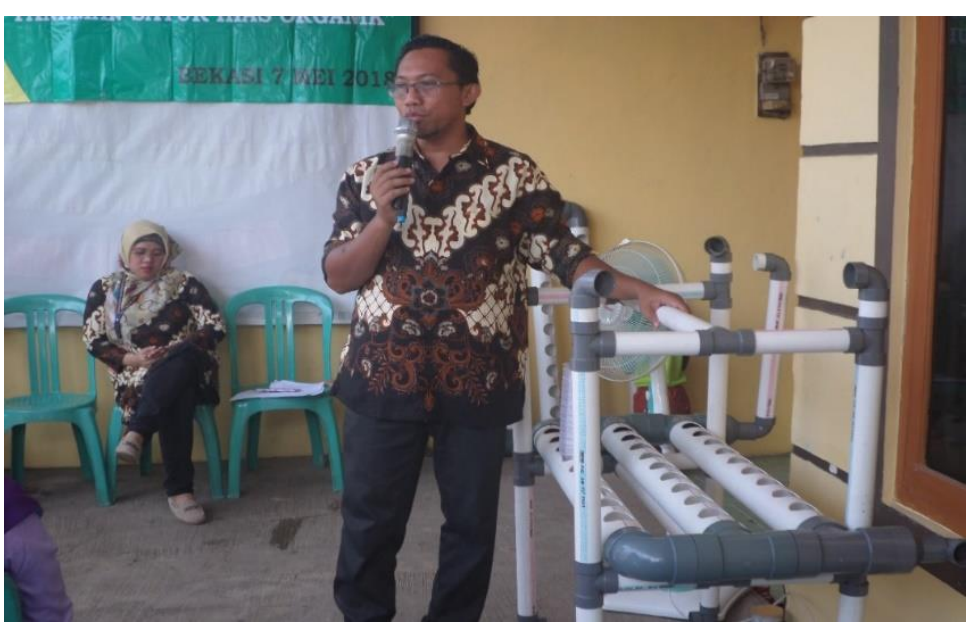

Kegiatan pengabdian kepada masyarakat ini dilakukan dengan metode ceramah dan memberikan pelatihan bagaimana cara membuat prototype media hidroponik, pembibitan, pembuatan pupuk cair hingga proses panen dan pemberian

keterampilan untuk keperluan pemasaran dari produk. 
Pada hari pertama seluruh peserta diberikan pengetahuan mengenai konsep ketahanan pangan dengan media hidroponik dan penjelasan mengenai tata cara pembibitan.

Seluruh peserta dalam pelatihan ini antusias dalam melakukan proses perakitan dan pembuatan media hidroponik, bahkan ada peserta yang sudah memiliki gambaran pengembangan prototype hidroponik.

Keberhasilan dari pemberian literasi kepada peserta mengenai ketahanan pangan pada masa pendemik terlihat dari keaktifan dan ketekunan para peserta dalam tahap pembibitan dan perawatan tanaman hidroponik. Proses pembibitan hingga pemanenan pada jenis tanaman sayuran hias yang diterapkan berkisar 18 sampai dengan 24 hari untuk mencapai tahap panen
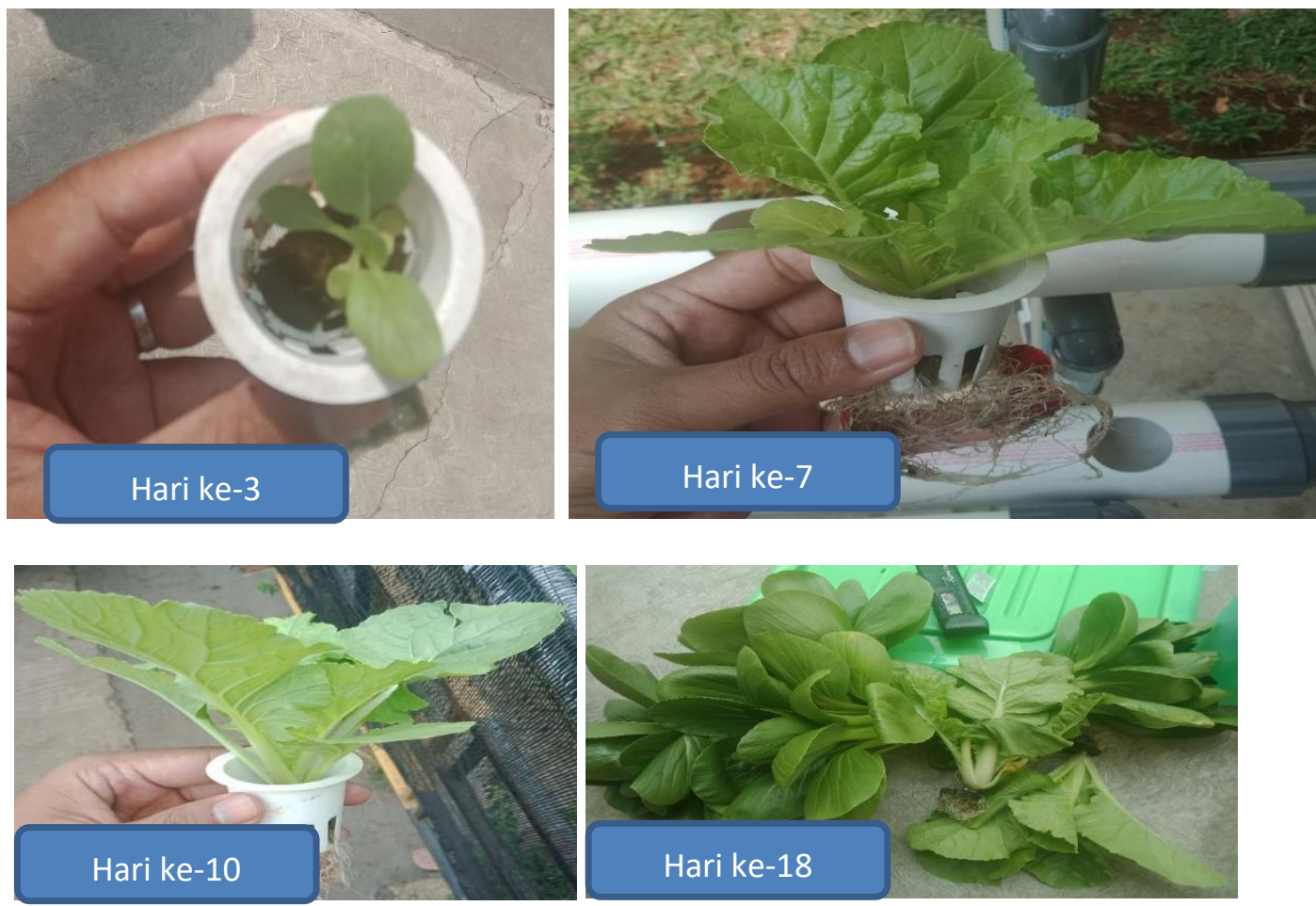

Keberhasilan tahap implmentasi awal dalam pembuatan prototype hidroponik telah dirasakan manfaatnya oleh masyarakat terutama oleh peserta pelatihan dari PKK Perum Mustika Karang Satria. 
Dengan memperhatikan kemudahan dalam perawatan terhadap sayuran hias organik dengan menggunakan model hidroponik, respon masyarakat sangat besar setelah merasakan manfaat terhadap ketahanan pangan keluarga. Dalam tahap evaluasi, tim pengabdi kembali melakukan survey terhadap keberlangsungan program hidropinik yang telah diinisiasi. Hasil yang ditemukan sangat menggembirakan dimana program eco-preneur dengan budidaya tanaman hidroponik dapat diterima dan terus dikembangkan. Berikut model hidroponik yang dikembangkan oleh para peserta pelatihan baik dirumah prinadi maupun di halaman sekitar
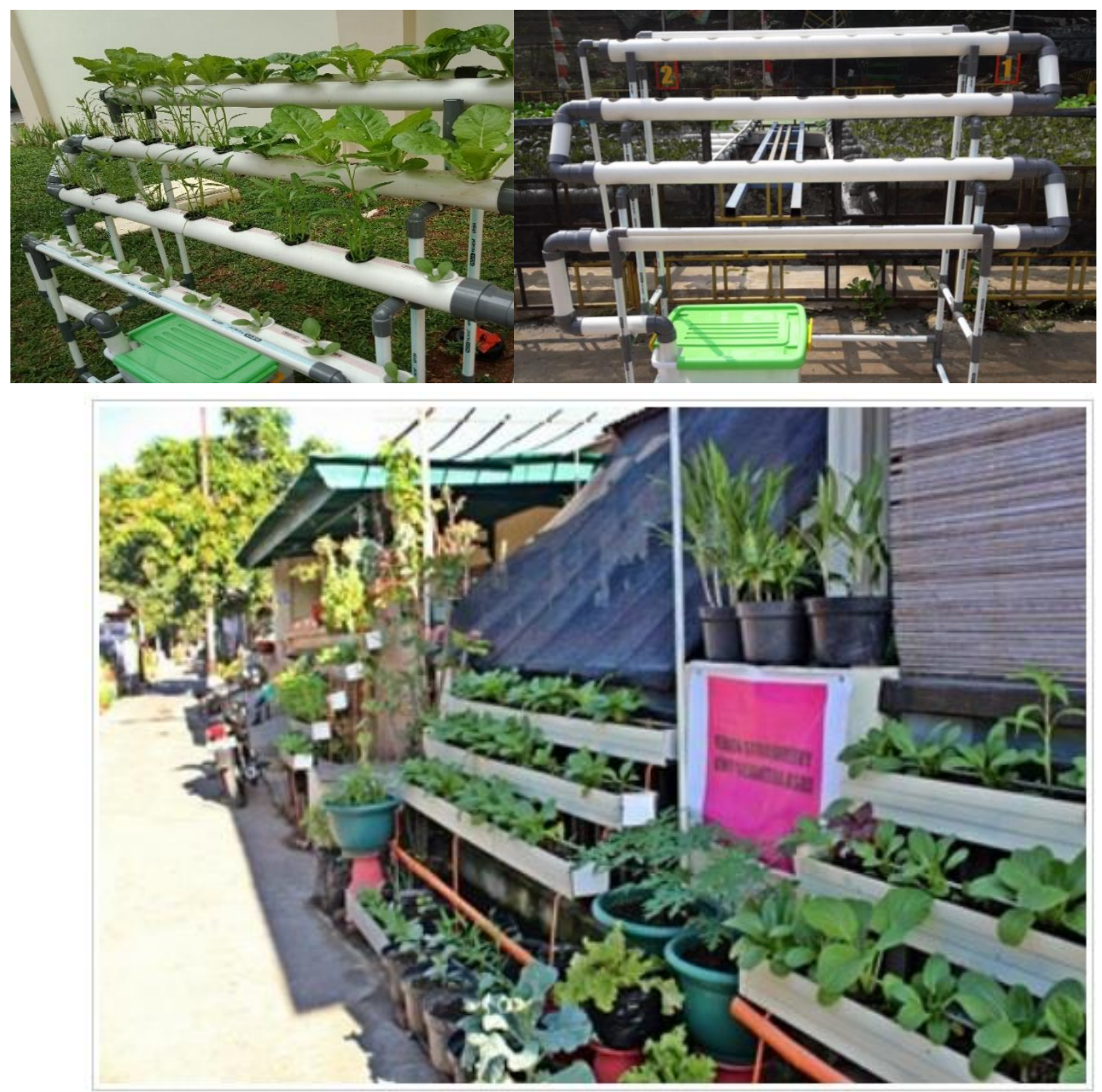
Ketahanan pangan keluarga secara mandiri terlihat berhasil dengan sejumlah metode dan media tanam yang dikembangkan oleh ibu-ibu PKK di Perumahan Mustika Karang Satria. Tanaman sayur hias organic tumbuh subur baik yang dikembangkan dengan metode hidroponik maupun dengan menggunakan media tanam lainnya

\section{Kesimpulan Dan Saran}

Setelah melaksanakan program pengabdian masyarakat ini dengan judul "Peningkatan Keterampilan Ecopreneur Pada Masa Pendemic Covid-19 Melalui Pelatihan Budidaya Tanaman Sayur Hias Organik ", dan setelah melakukan evaluasi dari proses pelaksanaan dan pada temuan-temuan yang kami peroleh selama pengabdian masyarakat, dapat kami simpulkan bahwa program pengabdian masyarakat sebagai salah satu wujud dari pelaksanaan tri dharma perguruan tinggi ini telah mampu memberikan manfaat bagi ibu-ibu pkk di perumahan mustika karang satria Bekasi yang menjadi sasaran pengabdian ini.

Bentuk pelatihan seperti ini merupakan salah satu cara yang efektif untuk memberikan penyegaran dan wawasan baru di bidang pemberdayaan sumber daya manusia (ibu-ibu pkk) dan sumber daya alam yang ada serta didukung seluruh pihak terkait yang melancarkan kegiatan pengabdian masyarakat yang kami laksanakan.

Ketahanan pangan keluarga secara mandiri dapat ditingkatkan melalui pelatihan ini dan juga memberikan dampak positif terhadap lingkungan yang menjadi lebih asri dan sejuk. Disisi lain keterampilan ecopreneur ibu-ibu PKK Mustika Karang Satria semakin berkembang dengan menjadikan budidaya tanaman sayur hias organic sebagai salah satu komoditi yang memiliki nilai ekonomis dan tentunya meningkatkan ketahanan pangan keluarga apalagi ditengah kondisi pendemic-19 yang sedikit banyak mempengaruhi mobilitas masyarakat secara umum. 


\section{DAFTAR PUSTAKA}

Agostiono, 2010, Implementasi Kebijakan Publik Model Van Meter dan Van Horn, http//kertyawitaradya.wordpre ss, diakses 5 September)

Edward III, George C (edited), 1990, Public Policy Implementing, Jai Press Inc, (London- England. Goggin, Malcolm L et al.)

Haedar Akib, dan Antonius Tarigan. 2008, Artikulasi Konsep Implementasi Kebijakan: Perspektif, Model dan Kriteria Pengukurannya, Jurnal Baca, Volume 1 Agustus (Makassar: Universitas Pepabari)

Harefa, Andrias, Membangkitkan Roh Profesionalisme, (Jakarta: PT Gramedia Pustaka Utama, 2009)

Kartajaya, Hermawan, On Process, Seri 9 elemen marketing (Bandung: Mizan, 2006)

Kiyosaki, RobertT, Sharon L. Lechter, C.P.A. Rich Dad Poor Dad for Teens Rahasia tentang uang yang tidak kau pelajari di sekolah, (Jakarta: PT Gramedia Pustaka Utama, 2005)

Kiyosaki, Robert, The Cashflow Quadrant (Jakarta: Gramedia Pustaka Utama, 2001)

Mazmanian, Daniel A and Paul A. Sabatier. 1983, Implementation and Public Policy, (USA, Scott Foresman and Company)

Muhammad, Safak, Cara mudah orang gajian menjadi entrepreneur (Jakarta: Media sukses 2006, cetakan ketiga)

Purwanto dan Sulistyastuti, 1991, Analisis Kebijakan dari Formulasi ke Implementasi Kebijakan, (Jakarta: Bumi Aksara)

Ripley, Rendal B. and Grace A. Franklin, 1986, Policy Implementation and Bureaucracy, second edition, the Dorsey Press, (Chicago-Illionis) 
Rogak, Liza, 100 Bisnis Pilihan Terbaik, Tidak terlalu Beresiko dan Menghasilkan (Jakarta: Eiexkomputindo, 2006)

Royan, Frans M, Membuka Toko, Alternatif Usaha mandiri (Semarang: Effhar \& Dahara Prize, 2007 cet ke sebelas)

Senduk, Safir, Buka Usaha Nggak Kaya Percuma, (Jakarta Elexkomputindo, 2007 Cet ke delapan)

Suharno, Bambang, Langkah Jitu memulai Bisnis dari No/(Jakarta: Penebar Plus, 2007 Cet kedelapan)

Tanuwijaya, William, 8 Intisari Kecerdasan Finansial, IImu baru yang tidak diajarkan di soklah dan kampus. (Yogyakarta: Medpresss, 2007)

Teguh, Mario, Becoming a Star, (Bandung: Syamil Cipta Media, 2005).

Waringin, Tung Desem, Financial Revolution(Jakarta: Gramedia Pustaka Utama, 2005).

Witarko, Djoko.dkk, Panduan Diskusi Thematik Rencana Aksi, Pembangunan yang diprakarsai Masyarakat, Buku 1 (Jakarta: Pusat Kajian Bina Swadaya, 2007) 